\title{
THE ARCHAEOLOGICAL COLLECTION FROM THE BORSK MUSEUM OF LOCAL HISTORY
}

\author{
Ekaterina V. Volkova \\ Research and Production Center Bifas, Samara, Russian Federation
}

Aleksey V. Denisov

Samara State University of Social Sciences and Education, Samara, Russian Federation

Olga V. Kuzmina

Samara Archeological Society, Samara, Russian Federation

\author{
Aleksey A. Lastovskiy \\ Research and Production Center Bifas, Samara, Russian Federation
}

\begin{abstract}
The paper describes a collection of random finds from the funds of the Borsk Museum of Local History. All of them originate from the territory of the Borsk district of the Samara region. The collection includes $\infty$ items from different eras. The Stone Age is represented with an item made from the elk's horn. Unique typological ㄱ. characteristics of the object allow us to consider it not as an ordinary clutch, but, perhaps, as a sceptre top. The most numerous finds is a group of materials from the Bronze Age, including stone axes, a pestle, a bronze sickle, a bronze dart tip, a clay spindle and bone a bead. A morphological analysis of the axes leads to the conclusion that they belong to the Fatyanovo and Balanovo cultures and they are the earliest of this type of objects in the Samara Volga region. The tip of the dart, according to its characteristics, has analogies in the monuments of the Abashevo culture. The sickle certainly belongs to the Srubna culture. Of particular interest is the ornamented clay spindle. Similarly shaped spindles are known in the monuments of the Sintashta, Pokrovskaya and Srubna $\varphi^{0}$ cultures, and the presence of the ornament lets suggest that this product could serve as a pommel. Quite a rare find is a large bone bead. Analogies to it are found in funerary monuments of the Pokrovskaya culture. Published materials of the Iron Age are represented by iron daggers, a sword, a spearhead and bronze arrowheads. Their typology and dating have been determined using the morphological analysis of weapons and a search for analogies in adjacent territories. The finds of the modern times include bronze combs, decorated with twin horse heads. Such metal zoomorphic combs were used by the Finno-Ugric peoples until the beginning of the $20^{\text {th }}$ century. These combs possibly descend from the bronze two-horse-headed noisy pendants of the $7^{\text {th }}-11^{\text {th }}$ centuries and comb-pendants of the $8^{\text {th }}-12^{\text {th }}$ centuries.

Key words: horn pommel, stone axe, sickle, dart, arrowhead, dagger, sword, spear, comb.

Citation. Volkova E.V., Denisov A.V., Kuzmina O.V., Lastovskiy A.A., 2018. The Archaeological Collection from the Borsk Museum of Local History. The Lower Volga Archaeological Bulletin, vol. 17, no. 2, pp. 108-127. (in Russian). DOI: https://doi.org/10.15688/nav.jvolsu.2018.2.9
\end{abstract}




\title{
АРХЕОЛОГИЧЕСКАЯ КОЛЛЕКЦИЯ ИЗ ФОНДОВ БОРСКОГО КРАЕВЕДЧЕСКОГО МУЗЕЯ
}

\author{
Екатерина Вячеславовна Волкова
}

Научно-производственный центр «Бифас», г. Самара, Российская Федерация

\author{
Алексей Владимирович Денисов \\ Самарский государственный социально-педагогический университет, г. Самара, Российская Федерация
}

\section{Ольга Викторовна Кузьмина}

Самарское археологическое общество, г. Самара, Российская Федерация

\section{Алексей Алексеевич Ластовский}

Научно-производственный центр «Бифас», г. Самара, Российская Федерация

Аннотация. В статье публикуется коллекция случайных находок из фондов Борского краеведческого музея. Все они обнаружены на территории Борского района Самарской области. Рассматриваемая коллекция включает предметы разных эпох. Каменный век представлен изделием из рога лося. Уникальные типологические характеристики предмета позволяют рассматривать его не как обычную муфту, а, возможно, как навершие скипетра. Наиболее многочисленной в публикации является группа материалов бронзового века, включающая каменные топоры, пест, бронзовый серп, бронзовый наконечник дротика, глиняное пряслице и костяную бусину. Морфологический анализ топоров позволил сделать вывод об их принадлежности фатьяновской и балановской культурам и отнести их к числу наиболее ранних в Самарском Поволжье. Наконечник дротика по своим характеристикам находит аналогии в памятниках абашевской культуры. Серп, безусловно, был изготовлен в рамках срубной культуры. Определенный интерес представляет орнаментированное глиняное пряслице. Аналогичные по форме приспособления известны по памятникам синташтинской, покровской и срубной культур, а наличие орнамента позволяет предположить, что данное изделие могло служить навершием. Довольно редкой находкой является крупная костяная бусина. Аналогии ей найдены в погребальных памятниках покровской культуры. Публикуемые материалы железного века представлены железными кинжалами, мечом, наконечником копья и бронзовыми наконечниками стрел. Благодаря морфологическому анализу предметов вооружения и поиску аналогий на сопредельных территориях определены их типология и датировка. К материалам нового времени относятся бронзовые гребни, украшенные парными конскими головками. Подобные металлические зооморфные гребни бытовали у финно-угорских народов вплоть до начала XX в. и, возможно, восходят к бронзовым биконьковым шумящим подвескам VII-XI вв. и подвескам-гребням VIII-XII веков.

Ключевые слова: роговое навершие, каменный топор, серп, дротик, наконечник стрелы, кинжал, меч, копье, гребень.

Цитирование. Волкова Е. В., Денисов А. В., Кузьмина О. В., Ластовский А. А., 2018. Археологическая коллекция из фондов Борского краеведческого музея // Нижневолжский археологический вестник. Т. 17 , № 2 . C. 108-127. DOI: https://doi.org/10.15688/nav.jvolsu.2018.2.9

В фондах Борского краеведческого музея хранится небольшая коллекция археологических экспонатов. Это предметы каменного, бронзового, железного веков, а также нового времени. Все они найдены случайно на территории Борского района Самарской области. Целью данной публикации является предварительный анализ и введение в научный оборот этих находок.

\section{Материалы каменного века}

Роговое изделие (БКМ, ОФ № 7687) (рис. 1). Эта находка по степени сохранности и древности претендует на исключительное место. Такими же уникальными являются типологические характеристики предмета. Для его изготовления взята часть так называемой «лопаты» лосиного рога с примы- 
The Archaeological Collection from the Borsk Museum of Local History

кающим отростком, видимо, близко к основанию. Отросток рога срезан и значительно укорочен таким образом, что превращен в клевец. Остаток отростка обработан шлифовкой и полировкой до такой степени, что в результате повышения температуры в этом процессе естественный цвет рога изменился на более темный. На поверхности клевца нет никаких царапин, мелких сколов и прочих повреждений, возникающих, например, на земледельческих орудиях в ходе работы ими. Обработкой выделены только функционально значимые части предмета, в то время как поверхность рога сохранила свою естественную фактуру.

В центре подпрямоугольного фрагмента роговой лопасти просверлено сквозное отверстие. Сверление проходило под углом к поверхности. Края этого отверстия также изменили цвет на более темный, что характерно при повышении температуры в результате сверления твердой органики.

На конце и по краям фрагмента лопасти рога располагается паз, образованный в результате выемки губчатой ткани рога и превращенный в глубокую полость. Полость занимает практически большую часть изделия и заканчивается у начала отростка рога.

Длина изделия $-21,7$ см, ширина $-10,6$ см, толщина $-4,6$ см, длина рогового отростка около 9 см, глубина выбранного паза по осевой 11,6 см, ширина паза - 1,4 см, диаметр отверстия $-2,6 \mathrm{~cm}$.

Нет однозначного решения вопроса о функциональном назначении данного рогового изделия. Морфологически близкие ему предметы получили условное название «мотыжки» по аналогии с роговыми орудиями для рыхления почвы. Такие изделия найдены при исследовании трипольских и среднестоговских энеолитических поселений.

Ареал распространения орудий ударного типа из рога лося и временной диапазон, в котором они известны, чрезвычайно широки. В пределах Восточной Европы подобные изделия известны в памятниках эпох мезолита энеолита. Во всех зафиксированных случаях для изготовления орудий использовались разные части рога: отростки, отростки с прилегающей частью основания, отростки вместе с фрагментом лопасти [Лозе, 1966, с. 113, рис. 3,3; Збенович, 1980, с. 98, рис. 65; Синюк, Клоков, 2000, рис. 91].

Все известные и описанные в литературе изделия делятся на следующие группы: роговые кайла, служившие для выработки в кремнедобывающих шахтах; роговые топоры; роговые вставки-вкладыши в составных орудиях как близкий аналог роговым топорам; муфты из отростков рога или фрагментов лопасти рога, используемые для крепления вкладыша; навершия из отростков рога, используемые как вотивные предметы, если диаметр отверстия для насада маленький, или как производственные орудия при большом диаметре отверстия для насада; лопатообразные орудия из фрагментов лопасти рога, используемые для рыхления почвы.

Экземпляр муфты, хранящийся в Борском музее, наиболее близок находкам, сделанным в Восточном Прионежье и относящимся к эпохе мезолита [Ошибкина, 1981, рис. 2,1,3]. Среди них есть как собственно муфты, так и изделия из отростков рога и лопатообразные орудия [Ошибкина, 2006, рис. 79,1-3]. Морфологически наиболее близкие борской находке изделия являются муфтами из фрагментов лопасти рога и со всей очевидностью составными топорами, не имеющими отношения к земледелию или простому рыхлению почвы. Подтверждением этому служат экземпляры подобных орудий с сохранившимися каменными вставками.

В то же время следует отметить, что, несмотря на обилие костяных и роговых предметов, находимых в мезолитических погребениях, роговые муфты не обнаружены ни в одном из них.

Изделие из Борского музея имело неясные нам функции, но некоторые предположения о его назначении сделать можно. Борский экземпляр, как уже отмечалось, отличается от известных изделий из лосиного рога наличием клевца и паза, расположенного не только на конце, но и по периметру фрагмента лопасти рога.

Наличие клевца исключает использование предмета в качестве земледельческого орудия - «мотыжки». Кроме того, трудно предположить, что в муфту вставлялся каменный вкладыш, поскольку, во-первых, паз слишком обширен и вставка крупного вкла- 
дыша на всю глубину паза сильно утяжеляет орудие, а во-вторых, паз устроен глубже, чем осевая линия рукояти в центре сверленного отверстия. Вкладыш в таком орудии упирается в рукоять, что усиливает отдачу и делает работу малоэффективной. Если же вкладыш был небольшим, невозможно закрепить его в глубоком пазу. Возможно, в столь глубокий паз вставлялось нечто иное, а не каменный вкладыш. Такой элемент конструкции, как глубокий паз, в сочетании с клевцом, на котором нет видимых следов работы, позволяет предположить использование изделия из Борского музея в качестве навершия скипетра. Отсутствие данных о контексте находки дает возможность предположить только широкие хронологические рамки для данного изделия, которые могут быть определены временем от эпохи мезолита до энеолита.

\section{Материалы бронзового века}

Топор (БКМ, ОФ № 2271) каменный, втульчатый (рис. 2,1). Обух короткий, цилиндрический, в сечении круглый. В области клина, вдоль спинки и брюшка топора, проходит ребро. Поверхность топора хорошо отполирована. Длина орудия - 17,1 см. Длина обушной части (до втулки) $-5,1$ см. Длина клина (до втулки)9,4 см. Диаметр отверстия со стороны брюшка $-2,9$ см, со стороны спинки $-2,3$ см.

Топор (БКМ, ОФ № 7686) каменный, втульчатый, ромбовидный в плане формы (рис. 2,2). Поверхность орудия хорошо отполирована. Сечение клина и обуха имеет вид квадрата со скошенными углами. По спинке, вдоль всего топора, проходит слабо выраженное ребро. Брюшко изделия плоское, хотя заметна слабая его вогнутость. Конец клина имеет прямоугольное сечение со скошенными углами, размерами $3,8 \times 1,5$ см. Длина клина равна длине обуха. Сечение топора имеет размеры 4,5 × 4,5 см, а пятка обуха $3 \times 3$ см. Диаметр отверстия со стороны спинки $-2,8$ см, со стороны брюшка $-2,3$ см.

Каменные топоры из Борского района являются первой находкой подобного типа в бассейне Самары. Это самые ранние среди известных топоров, происходящих из Самарского Поволжья [Кузьмина, 2006], что под- тверждается и таким признаком, как прямое брюшко (клин не отделен от обуха).

Топоры различаются между собой морфологически, что объясняется их разной хронологической позицией. Топор (БКМ, ОФ № 7686) имеет более раннюю ромбовидную форму с почти равными по длине клином и обухом. Все стороны его плоские. Топор (БКМ, ОФ № 2271) имеет более позднюю форму с выделенными в плане клином и коротким обухом. Все стороны его выпуклые.

Если же смотреть шире Самарского Поволжья, то аналогичные топоры хорошо известны и широко распространены. Судя по сводке А.Я. Брюсова и М.П. Зиминой, топор (БКМ, ОФ № 7686) относится к типу клиновидных [Брюсов, Зимина, 1966, табл. 14], а топор (БКМ, ОФ № 2271) - к типу обушковых [Брюсов, Зимина, 1966, табл. 15-16].

По классификации фатьяновских топоров топор (БКМ, ОФ № 7686) относится к типу ромбических молотковидных [Крайнов, 1972, рис. 14,11], а топор (БКМ, ОФ № 2271) - к типу обушковых усеченноконических [Крайнов, 1972, рис. 14,21].

По классификации каменных сверленых топоров, происходящих с территории распространения памятников балановской культуры, топор (БКМ, ОФ № 7686) из Борского музея относится к типу обушковых усеченноконических [Бадер, Халиков, 1976, табл. 42,12], а топор (БКМ, ОФ № 2271) условно можно отнести к типу короткообушковых [Бадер, Халиков, 1976, табл. 44,1].

Таким образом, каменные сверленые топоры из Борского музея могут быть признаны одновременно балановскими и фатьяновскими.

Топор-молот (БКМ, ОФ № 7688) каменный, с широким перехватом для крепления к рукояти (рис. 3,1$)$. Орудие довольно массивное. Со стороны брюшка изделие имеет желобок, по всей видимости, естественного происхождения. Конец клина обломан. Следы сколов, вероятно, возникшие в процессе работы, видны по всему орудию. Топор шлифовался дважды: в момент изготовления и после появления на нем сколов. Длина топора-молота $-21,6$ см, клина $-9,9$ см, перехвата $-7,2$ см, обуха $-4,2$ см. Ширина клина $-9,8$ см, перехвата $-8,9$ см, обуха $-10,6$ см. 
The Archaeological Collection from the Borsk Museum of Local History

Подобные топоры-молоты происходят с поселений эпохи бронзы Алексеевское [Кривцова-Гракова, 1948, рис. 46,2], Камышное II [Потемкина, 1985, рис. 34, 13], Грушеваха, Зливки, Снежковка-7 [Берестнев, 2001, рис. $82,4-6]$.

Пест (БКМ, ОФ № 1972) каменный, усеченноконической формы (рис. 3,2). Рабочая часть песта совершенно плоская и в сечении идеально круглая. Высота песта - 13 см, диаметр рабочего конца $-6,7$ см.

Аналогичные орудия происходят с поселений эпохи бронзы Малоиргизское, [Памятники..., 1993, табл. 34,3], Мосоловское [Пряхин, 1996, рис. 34].

Наконечник дротика (БКМ, ОФ № 7811) бронзовый, литой. Перо имеет форму вытянутого треугольника (рис. 4,1). Черешок широкий, плоский, с закругленной пяткой. Наконечник заострен по всему периметру, включая пятку. Максимальная толщина приходится на центральную продольную ось изделия. Длина наконечника $-7,4$ см, ширина пера $-1,8$ см. Толщина пера и черешка $-0,5$ см.

Данное изделие может быть отнесено к наконечникам дротиков абашевской культуры. Близкие ему происходят из могильников: Абашево, насыпь V, могила 4, костяк 1 [Смолин, 1928, рис. 24,7], Метев-Тамак, могила 3 [Збруева, 1958, рис. 5,14], Алгаши, кург. 4, погр. 3 [Ефименко, Третьяков, 1961, рис. 9,9], НижнеЧуракаевский, ограда А, погр. 4 [Сальников, 1967 , рис. 2,9], Тугаевский курган [Горбунов, 1986, табл. XIV,17], Ст. Ябалыклы, кург. 10, погр. 1 [Горбунов, Морозов, 1991, рис. Х,7]; Баишево IV, кург. 1 [Обыденнов, Обыденнова, 1996, рис. 34,6], пос. Тюбяк, раскоп III [Обыденнов и др., 2000, рис. 75,10]. Эти наконечники не имеют четко выраженной, стандартной формы, но объединяются в одну категорию благодаря таким признакам, как небольшие размеры, подтреугольная форма короткого пера, черешковый насад. Размеры их близки. Длина - 4,4-7,4 (10) cм, наибольшая ширина $-1,7-2,4$ см. Различия сводятся к формам пера, черешка (широкого или узкого) и пятки (от плоско срезанной до ромбовидной).

Серп (БКМ, ОФ № 7685) бронзовый, литой, с креплением в виде крюка (рис. 4,4 ). Рабочая часть орудия деформирована (изог- нута). Носок клинка закруглен. Край лезвия и носок с обеих сторон откован и заточен. Крюк выделен уступом. Длина серпа - примерно 31,7 см. Максимальная ширина клинка серпа - 5,7 см. Высота дуги (от хорды до наибольшего изгиба лезвия) -4 см. Край спинки клинка утолщен до 0,4 см. Толщина крюка $-0,35$ см.

Серп из Борского музея относится к наиболее распространенным серпам эпохи поздней бронзы Восточной Европы, а именно к Приуральскому варианту Волго-Уральской группы типа Ибракаево. Эти орудия производились в рамках срубной культуры [Дергачев, Бочкарев, 2002, с. 59-68, 298].

Пряслице/навершие (БКМ， ОФ № 6616/1) глиняное, биконической формы (рис. 4,3 ). Вся поверхность изделия орнаментирована двумя неровными рядами тонких, редко поставленных ногтевых вдавлений (длина отпечатка ногтя - 0,8 см). Высота изделия $-2,5$ см, максимальный диаметр 3,1 см, диаметр по основанию изделия $-1,9$ см, диаметр отверстия втулки $-0,6$ см.

Аналогичное по форме биконическое пряслице происходит из Синташтинского грунтового могильника, погребение 39 [Генинг и др., 1992, рис. 127,4].

Орнаментированные глиняные пряслица встречены в ряде памятников покровской и срубной культур. Орнамент на этих изделиях повторяет орнамент на сосудах. Чаще всего это отпечатки полой косточки, как на изделиях с поселений Первое Сусканское [Мерперт, 1958, рис. 14,1-2; Пряхин, 1996, рис. 65,1$]$, Малоюлдашево I [Евгеньев и др., 2016, рис. 49,1], Лебяжинка V [Кузьмина и др., 2017, рис. 70,2], I Шигонское [Кузьмина, 2017, рис. 27,1], Кротовское [Васильева и др., 2017, рис. 12,12], Русская Селитьба [Колев, Королев, 2017, рис. 30,12].

Наличие орнамента на этих изделиях и присутствие их в погребениях позволяет предположить, что это навершия, аналогичные костяным и каменным, но сделанные из другого материала, а именно керамические.

Бусина (БКМ, ОФ № 6616) костяная, шаровидной формы (рис. 4,2). Бусина имеет высоту 1,5 см. Ее диаметр - 1,5 см. Диаметр отверстия $-0,5$ см. Вся внешняя поверхность хорошо залощена. Это довольно редкая находка. Аналогичная бусина происходит из могиль- 
ника Сиуч II, 2/1, исследованного в Ульяновском Поволжье (материалы не опубликованы). Бусина из могильника Сиуч II орнаментирована. В целом разнообразные поделки из кости, как правило, орнаментированные, характерны для покровской культуры, что позволяет отнести к их числу и бусину из Борского музея.

\section{Материалы раннего железного века}

Железный кинжал (БКМ, ОФ № 7706) имеет серповидное навершие подпрямоугольного сечения. Концы перекрестия слегка расширяются (рис. 5,1). Перекрестие прямое. Рукоять имеет подквадратное сечение со скругленными краями. Клинок клиновидной формы, ромбического сечения. Общая длина кинжала $-32,5$ см. Длина клинка $-21,5$ см, ширина у перекрестия $-4,5$ см, толщина $-0,6 \mathrm{~cm}$. Длина рукояти $-8,2 \mathrm{~cm}$, ширина $-0,9 \mathrm{~cm}$, толщина $-0,7$ см. Высота навершия $-6,7 \mathrm{~cm}$, ширина в районе крепления к рукояти $-0,5$ см, ширина раскованной части - $0,7 \mathrm{~cm}$, размеры перекрестия - 6,4 ×0,6 cм.

Традиционно мечи и кинжалы с серповидным навершием и прямым перекрестием датируются в пределах конца IV - I вв. до н.э. [Мошкова, 1963, с. 34; Клепиков, 2007 , с. 54 ; Скрипкин, 1990 , с. 118-119]. Необходимо отметить, что первые кинжалы с прямым перекрестием и навершием в виде изогнутого бруска на территории Урало-Поволжья появляются уже в первой половине IV в. до н.э. [Денисов, Мамедов, 2014, с. 157168 , рис. 1-3]. В то же время, среди этих «ранних» кинжалов отсутствуют находки с навершием, расширяющимся на концах. В связи с этим публикуемый кинжал стоит датировать III-I вв. до н.э.

Железный кинжал (БКМ, ОФ № 6750) имеет кольцевое навершие, изготовленное из округлого в сечении прутка, насаженного на рукоять (рис. 5,2). Перекрестие прямое. Рукоять прямоугольного сечения. Клинок с почти параллельными лезвиями, сходящимися в последней трети, имеет уплощенно-ромбическое сечение. Общая длина кинжала 39,9 см. Длина клинка - 27 см, ширина у перекрестия $-4,2$ см, толщина $-0,5$ см. Длина рукояти $-8,4$ см, ширина $-2,1 \mathrm{~cm}$, толщина 0,4 см. Размеры навершия $-4,8 \times 4,2$ см, тол- щина прутка - 0,6 см. Размеры перекрестия $5,8 \times 0,5$ см.

Кинжалы с подобным оформлением рукояти датируются в пределах III в. до н.э. II в. н.э. [Клепиков, 2007, с. 57; Сергацков, 2007, с. 61].

Железный меч (БКМ, ОФ № 6750), найденный у с. Петровка (рис. 6,4), ранее уже неоднократно публиковался [Исмагилов, Скарбовенко, 1977, с. 89-90, рис. 3,4; Мышкин, Скарбовенко, 2000, с. 18, табл. 10,3; Денисов, Мышкин, 2008, с. 66, 67, рис. 3,8]. Тем не менее было принято решение поместить его в публикацию, чтобы представить коллекцию музея в полном виде.

Меч имеет навершие в виде обращенных друг к другу затылками голов животных, предположительно, медведей. Под навершием находится небольшая колодочка в виде рельефного пояска, орнаментированного точечными углублениями. Перекрестие узкой бабочковидной формы сварено из двух полос. Рукоять в центральной части имеет округлое сечение, а в районе перекрестия приближается к овальному. Клинок имеет форму сильно вытянутого треугольника, уплощенно-ромбического сечения. Общая длина меча $-60,1 \mathrm{~cm}$. Длина клинка $-47,4$ см, ширина у перекрестия 5,5 см, толщина $-0,5$ см. Длина рукояти $-7,6 \mathrm{~cm}$, ширина в центральной части $-2,3$ см, толщина 2,1 см. Размеры навершия - 5,6 × 2,3 x 1,4 cм. Размеры перекрестия $-8 \times 3 \mathrm{~cm}$.

Авторы первой публикации предложили датировать этот меч V-IV вв. до н.э. [Исмагилов, Скарбовенко, 1977, с. 90]. К настоящему моменту нет возможности значительно сузить предложенную ими датировку.

Бронзовый наконечник стрелы (БКМ ОФ № 7810). Двухлопастной наконечник с короткой выступающей втулкой (рис. 5,4). Головка наконечника лавролистной формы. На одной из лопастей отмечены 10 косых прочерченных насечек. От этой же лопасти вниз опускается шип. На втулке имеется литейный дефект - продолговатое подпрямоугольное отверстие. Общая длина наконечника $-4,6$ см, длина пера -4 см, длина втулки $-0,6$ см, диаметр втулки $-0,7$ см, глубина втулки $-1,7 \mathrm{~cm}$, длина шипа -1 см.

Данный наконечник относится к типу 1 отдела I по К.Ф. Смирнову [Смирнов, 1961, 
The Archaeological Collection from the Borsk Museum of Local History

c. 38, табл. I]. По мнению С.Ю. Гуцалова, наконечники стрел данного типа на территории Южного Приуралья датируются в рамках VII-VI вв. до н.э. и к концу VI в. до н.э. выходят из употребления [Гуцалов, 2004, с. 18, табл. 10].

Подобные наконечники, происходящие с территории Нижнего Поволжья, М.А. ОчирГоряева отнесла к типу 1,4 отдела I своей типологии. Для Нижнего Поволжья автором было выделено две группы колчанных наборов. Тип 1,4 попадает в первую группу, датирующуюся второй половиной VI - первой половиной V вв. до н.э. [Очир-Горяева, 1996, c. $45,52-54]$.

Схожую дату для подобных наконечников предлагает П.М. Соколов. Наконечники, подобные борскому экземпляру, он относит к типу $2 б$ первого отдела первой группы. Подобные наконечники, по мнению автора, используются на территории Нижнего Поволжья в пределах второй половины VI - начала V в. до н. э. [Соколов, 2010 , с. $215,221,223]$. Необходимо отметить, что и М.А. Очир-Горяева, и П.М. Соколов основывают свои типологические и хронологические разработки исключительно на материалах савроматских погребений Нижнего Поволжья и не учитывают случайные находки. На территории Нижнего Поволжья савроматских погребений ранее второй половины VI в. до н.э. нет. В то же время наиболее ранние наконечники стрел с территории Урало-Поволжья в основном являются случайными находками.

Таким образом, наконечник можно датировать в рамках VII - начала V в. до н.э.

Бронзовый наконечник стрелы (инвентарный номер отсутствует). Трехлопастной наконечник с выступающей втулкой (рис. 5,3 ). Головка наконечника достаточно узкая, по форме приближающаяся к треугольной. Из трех лопастей две срезаны под прямым, а одна - под тупым углом ко втулке. Стрела отлита крайне небрежно: литейный брак наблюдается как на втулке, так и на лопастях. Общая длина наконечника $-2,9$ см, длина лопасти $-2,2$ см, длина втулки - 0,7 см, диаметр втулки - 0,5 см, глубина втулки - 1,1 см.

Данный наконечник относится к типу 9 (треугольная форма головки) или же позднему варианту типа 6 (сводчатая форма голов- ки) отдела II по К.Ф. Смирнову. Оба типа тесно связаны между собой и часто лежат в одних и тех же колчанах. И тип 9, и тип 6 появляются в VI в. до н.э. Поздние варианты этих наконечников трудно различимы: их характеризуют вытянутые пропорции, малый размер и большое количество брака при отливке. Подобные наконечники датируются в пределах IV-II вв. до н.э. При этом необходимо отметить, что бронзовые наконечники стрел, начиная с III в. до н.э., постепенно вытесняются железными черешковыми наконечниками. Во II в. до н.э. бронзовые наконечники встречаются крайне редко и могут считаться пережитком [Мошкова, 1963, с. 31; Смирнов, 1961, с. 46-49, табл. II, III].

М.А. Очир-Горяева отнесла подобные наконечники к типу 1,2 отдела II. Тип 1,2 попадает во вторую группу колчанных наборов, датирующуюся второй половиной $\mathrm{V}-$ первой третью IV в. до н.э. [Очир-Горяева, 1996, c. $46,53,54]$.

Если обратиться к работе П.М. Соколова, то публикуемый наконечник относится к типу 5а третьего отдела первой группы. Подобные наконечники появляются в V в. до н.э., во второй его половине тип 5 становится преобладающим, активно используется в IV в. до н.э. и, возможно, продолжает использоваться в III в. до н.э. [Соколов, 2010, с. 216, 221].

Таким образом, для наконечника из Борского музея можно предложить дату VIII вв. до н.э.

Железный наконечник копья (БКМ, ОФ № 6615). Перо остролистной формы с максимальным расширением в нижней трети (рис. 6,3). Сечение пера ромбическое, по центру идет еле заметное ребро жесткости. Втулка разомкнутая, нижняя ее часть разрушена коррозией. Характерной особенностью данного наконечника является малый диаметр шейки насада наконечника (узкая часть втулки наконечника, служащая основанием пера). Общая длина наконечника - 33 см. Длина пера 19 см, ширина $-3,4$ см, толщина - 0,7 см. Втулка имеет длину 13,9 см, диаметр $2 \times 2,1$ см и толщину стенки 0,1 см. Диаметр шейки насада равен $0,9 \mathrm{~cm}$.

Датировка и культурная атрибуция случайно найденных наконечников копий достаточно затруднительна, так как они зачастую 
не обладают столь типологически выраженными признаками, как наконечники стрел и клинковое оружие. Тем не менее наконечник из Борского музея, на наш взгляд, ближе всего к типу 2а по А.В. Симоненко [2009, с. 73].

Наконечник копья, близкий по форме, был найден в Поволжье, во впускном погр. 2, в Журовом кургане. Еще несколько наконечников данного типа были найдены в Причерноморье: Квашино, Великоплоское, Марьевка. Все они датируются в пределах II-I вв. до н.э. [Симоненко, 2009, с. $72,78,79$, рис. $47,53,1]$. Стоит отметить еще два наконечника копья, имеющих сходные черты. Это наконечник копья из погребения № 26 меотского Усть-Лабинского могильника, датируемый III-I вв. до н.э., и наконечник из язигского погребения в ЧонградВендельшалом, датируемый II в. до н.э. [Хазанов, 2008 , с. 111,115 , рис. $26,3,29,10]$.

Таким образом, наконечник копья из коллекции Борского краеведческого музея может быть отнесен к раннесарматской культуре и датирован II-I вв. до н.э.

\section{Материалы нового времени}

Бронзовые биконьковые гребни. Гребень № 1 (инвентарный номер отсутствует) практически целый, с двумя утраченными зубцами. От гребня № 2 (инвентарный номер отсутствует) сохранился лишь фрагмент, составляющий немногим более половины приспособления. Оба гребня односторонние, изготовлены из тонкой пластины с фигурными прорезями и украшены парными конскими головками, направленными в разные стороны, а также гравированным орнаментом поверх пластины. Гребни трапециевидные, рамчатые. История их обнаружения неизвестна.

Гребень № 1 (рис. 6,2) длиной 73 мм, высотой 42 мм и толщиной около 1-1,5 мм. Длина зубцов - 13 мм. Спинка гребня прямая, оформлена двумя головками коней, смотрящих в разные стороны. Головы коней выполнены в изящных пропорциях, но переданы достаточно условно, без прорисовки деталей. Кроме того, гребень имеет парные фигурные прорези. Две из них, находящиеся в центре пластины, имеют форму замочной скважины. И две, находящиеся по краям, имеют форму неровного полуовала. В верхней части (на спинке) в центре гребень имеет полукруглую петлю с круглым отверстием для подвешивания. По периметру гребневой пластины на обеих плоскостях изделия нанесен орнамент в виде зигзага, который заходит также на шеи конских изображений. Изначально гребень имел 15 зубцов, 2 из которых утрачены полностью, 2 обломаны наполовину, еще несколько деформированы.

Гребень № 2 (рис. 6,1) в общих чертах повторяет форму гребня № 1. Длина сохранившейся части -43 мм, высота -42 мм, толщина - 1-1,5 мм. Длина зубцов - около 13 мм. Изначально гребень № 2 был также украшен двумя парными конскими головками, а также двумя парами прорезей той же формы, что и на гребне № 1. В верхней части гребень № 2 также имеет петлю с неровным округлым отверстием для подвешивания. На одной из сторон гребневой пластины гребня № 2 фиксируется зигзагообразный орнамент. Существенным отличием гребня № 2 является наличие декора в виде имитации клепок. Первоначально гребень имел 15 или 16 зубцов. В настоящий момент сохранились 8 с половиной зубцов.

Впервые гребень рассматриваемого типа был опубликован П.С. Ефименко в 1874 году. Автор указывает, что крестьяне Архангельской области носили подобные медные гребни, привешивая их к тесемке, которая служила поясом для нижней одежды. На момент написания статьи П.С. Ефименко гребни рассматриваемого типа все еще были в ходу, но считались старинными [Ефименко, 1874, с. 50].

По классификации О.А. Кондратьевой гребни из коллекции Борского краеведческого музея относятся к группе поздних зооморфных гребней, к типу I. Согласно ее данным подобные приспособления бытовали преимущественно в крестьянской среде в Архангельской и Вологодской губерниях, в Поволжье и Пермском Предуралье. Причем, известные находки из Поволжья принадлежали финноугорским народам (марийцы, мордва, удмурты) [Кондратьева, 2011, с. 30].

По данным О.А. Кондратьевой зооморфные металлические гребни рассматриваемого типа относятся к XVIII-XIX векам. Н.И. Шутова указывает, что металлические гребни, навершия которых состоят из пары, двух или трех пар конских голов, были широко распрост- 
The Archaeological Collection from the Borsk Museum of Local History

ранены у удмуртов в XVIII - начале XX в. [Шутова, 2001, с. 176].

Нельзя исключать более раннее бытование зооморфных металлических гребней. В литературе есть упоминания о подобных находках из мордовских и удмуртского могильников, относящихся к XVII-XVIII вв. [Кондратьева, 1985, с. 455; Синицын, 1946, с. 77]. О.А. Кондратьева упоминает примеры похожих изделий более раннего времени (XIII-XIV вв.), известные в Чебоксарах и Биляре. Известно об аналогичном гребне из раскопок 2015 г. в Нижнем Новгороде. Но эти находки единичны и не всегда находятся в четко датируемом слое. В частности, городские находки (Нижний Новгород, Че- боксары) часто находятся в перемешанном слое, где культурные напластования XIII$\mathrm{XIV}$ вв. прорезаются более поздними сооружениями XVIII-XIX вв. [Краснов, Каховский, 1978, с. 16-17].

Таким образом, если верхняя дата бытования исследуемых гребней - конец XIX начало XX в. - не вызывает сомнений, установить нижнюю хронологическую границу сложнее. Возможно, металлические биконьковые гребни существовали одновременно с костяными (роговыми), являясь преемниками бронзовых биконьковых шумящих подвесок VII-XI вв. и подвесок-гребней VIII-XII вв. с зооморфными навершиями, нижняя часть которых имитирует зубья гребня. 


\section{ИЛЛЮСТРАЦИИ}

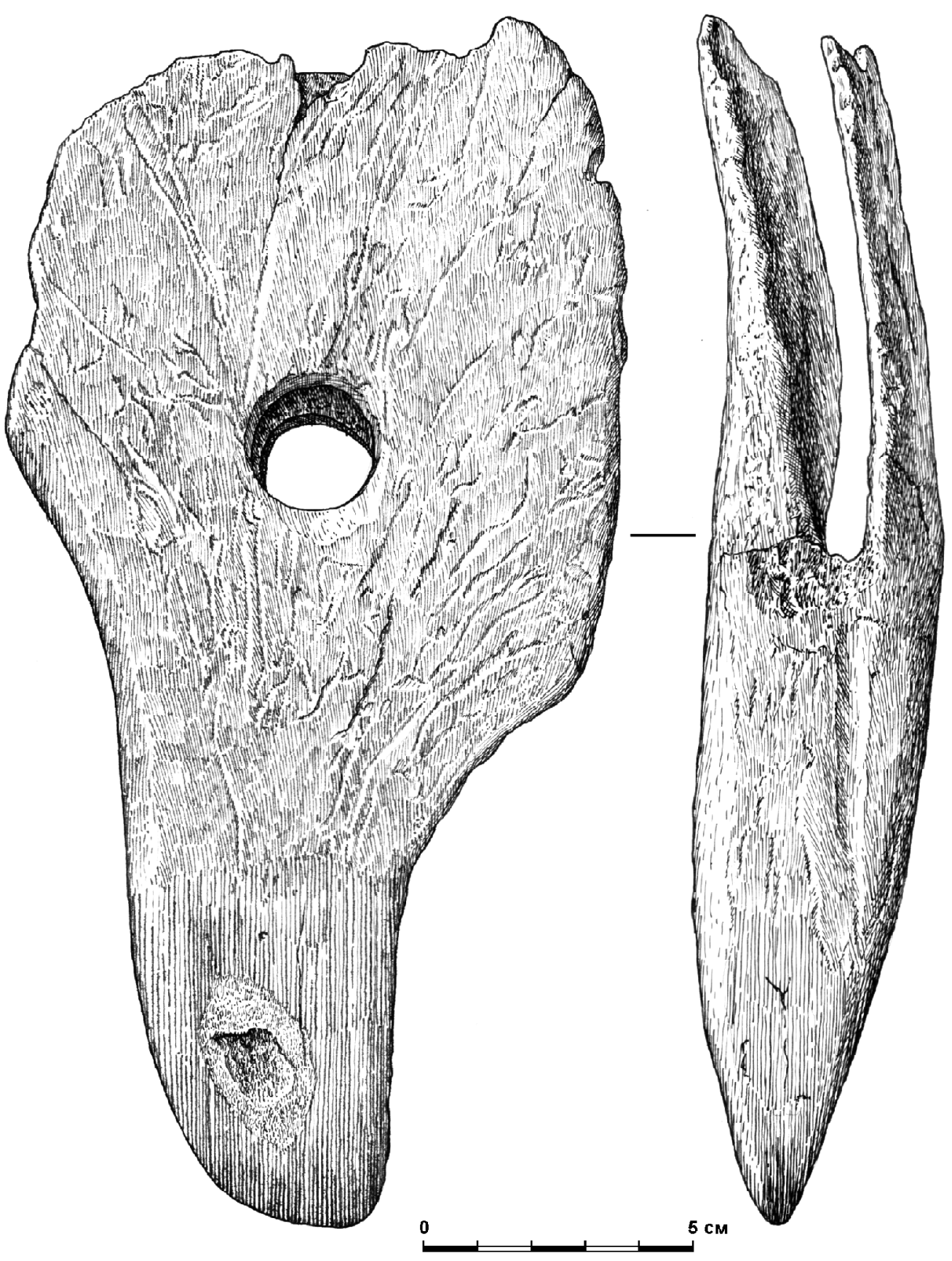

Рис. 1. Случайные находки из фондов Борского музея. Изделие из рога лося (БКМ, ОФ № 7687)

Fig. 1. The Archaeological Collection from the Borsk Museum of Local History. The item made of horn pommel (BKM, OF No. 7687) 

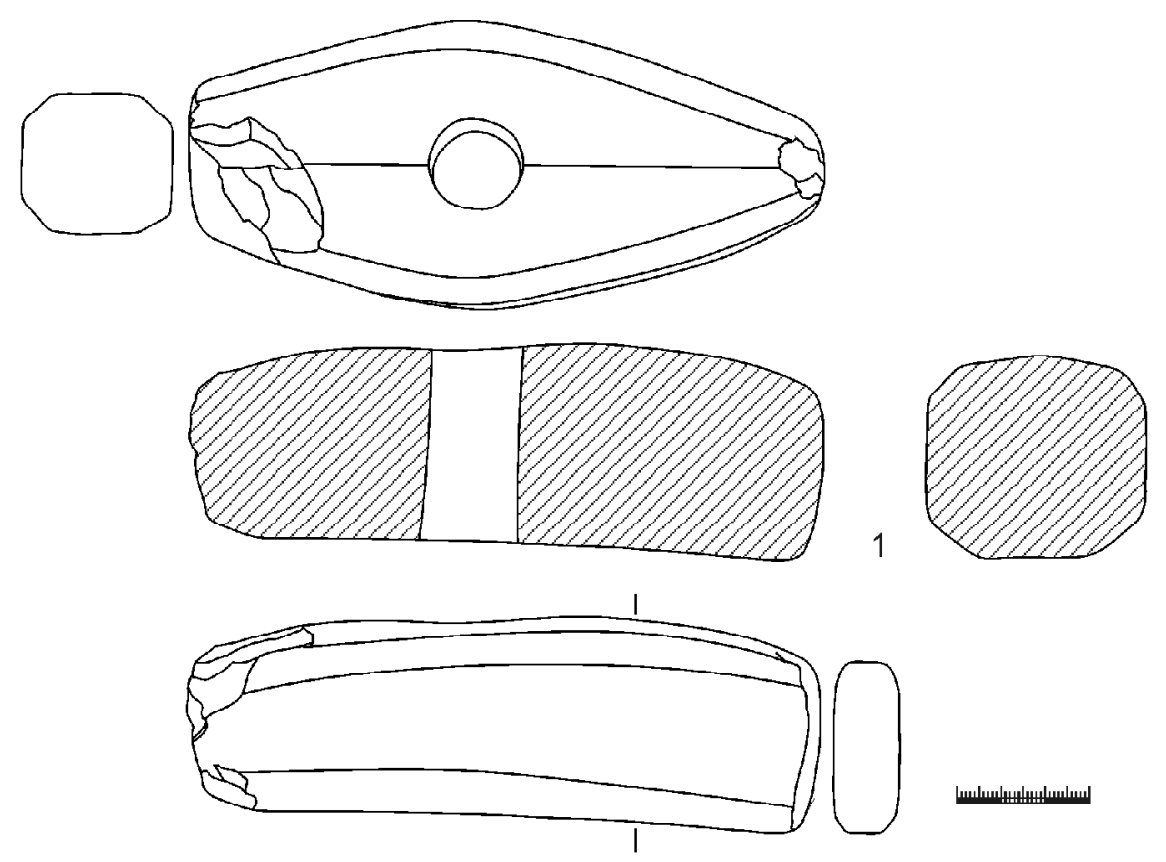

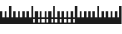
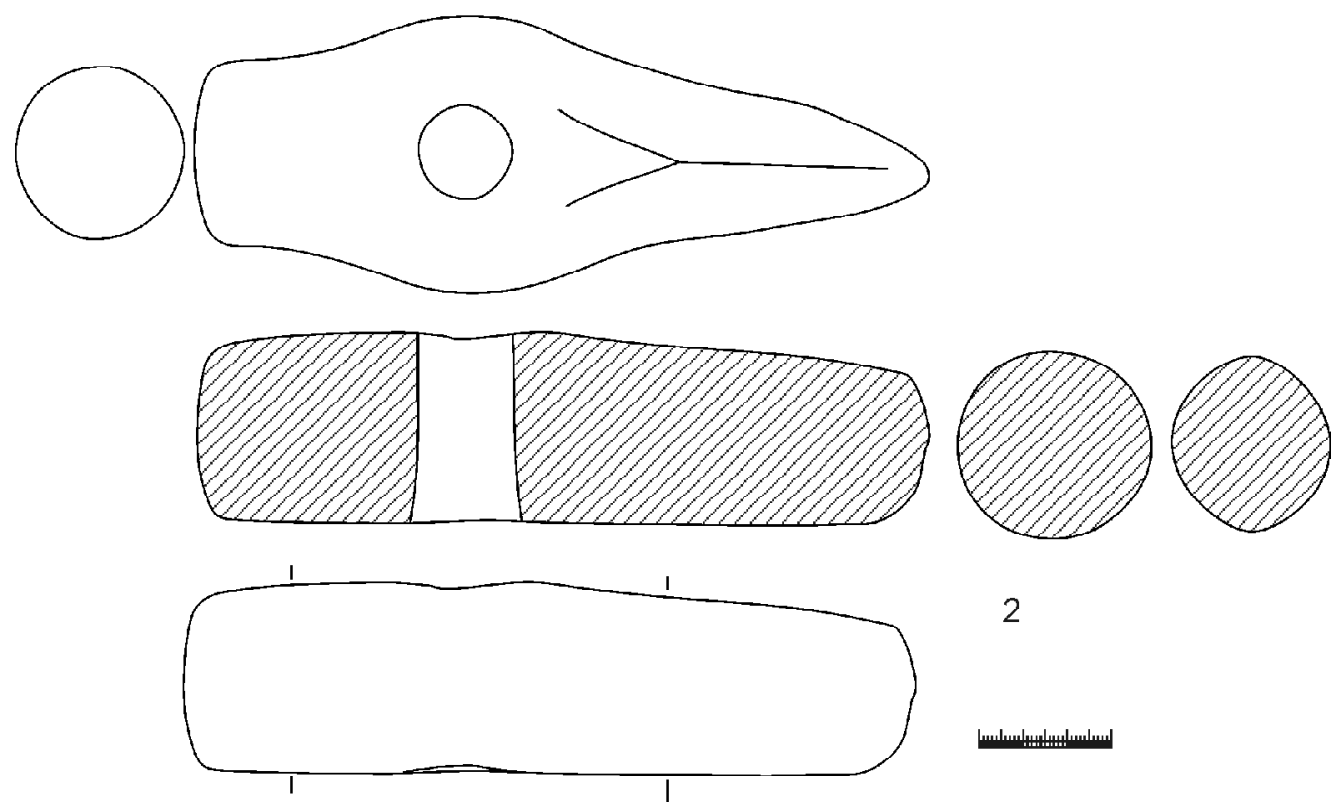

2

Рис. 2. Случайные находки из фондов Борского музея:

1 - топор (БКМ, ОФ № 2271); 2 - топор (БКМ, ОФ № 7686) (1-2 - камень)

Fig. 2. The Archaeological Collection from the Borsk Museum of Local History. 1 - axe (BKM, OF No. 2271); 2 - axe (BKM, OF No. 7686) (1-2-stone) 

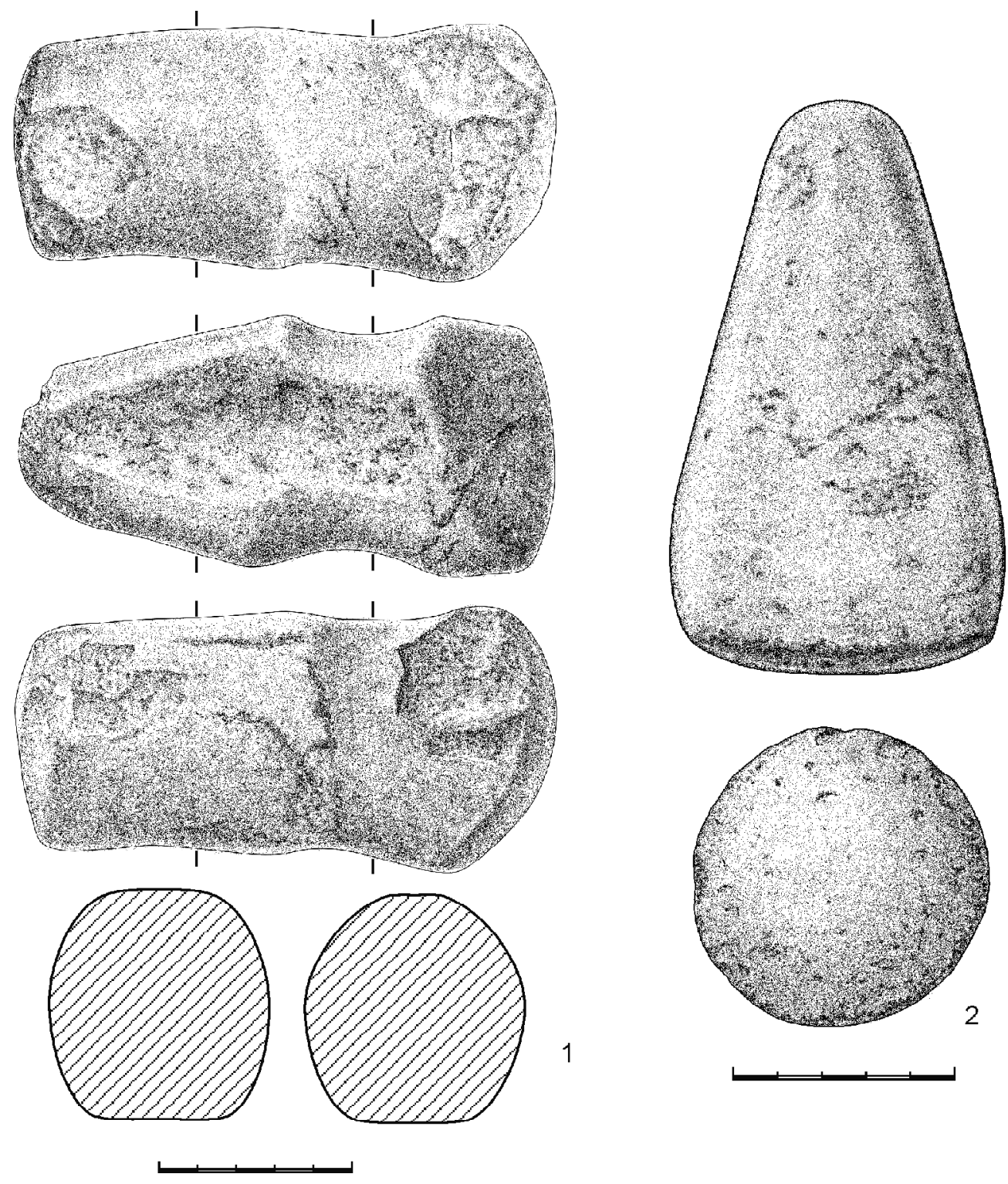

Рис. 3. Случайные находки из фондов Борского музея:

1 - топор-молот (БКМ, ОФ № 7688); 2 - пест (БКМ, ОФ № 1972) (1-2 - камень)

Fig. 3. The Archaeological Collection from the Borsk Museum of Local History: 1 - hammerhead (BKM, OF No. 7688); 2 - pestle (BKM, OF No. 1972) (1-2 - stone) 


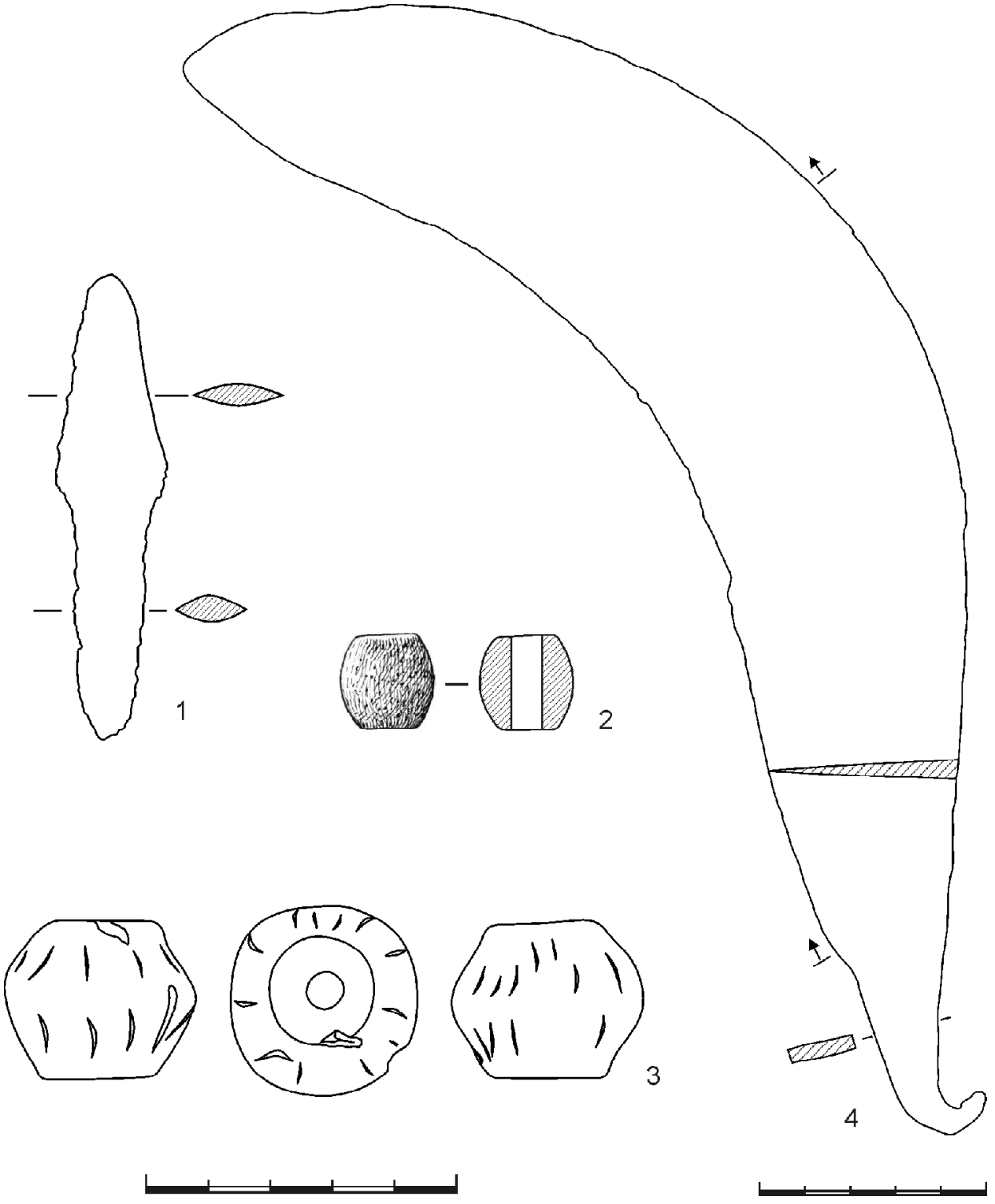

Рис. 4. Случайные находки из фондов Борского музея:

1 - наконечник дротика (БКМ, ОФ № 7811); 2 - бусина (БКМ, ОФ № 6616); 3 - пряслице (БКМ, ОФ № 6616/1); 4 - серп (БКМ, ОФ № 7685) (1, 4 - бронза; 2 - кость, 3 - глина)

Fig. 4. The Archaeological Collection from the Borsk Museum of Local History:

1 - dart tip (BKM, OF No. 7811); 2 - bead (BKM, OF No. 6616); 3 - spindle (BKM, OF No. 6616/1); 4 - sickle (BKM, OF No. 7685) (1,4 - bronze; 2 - bone; 3 - clay) 

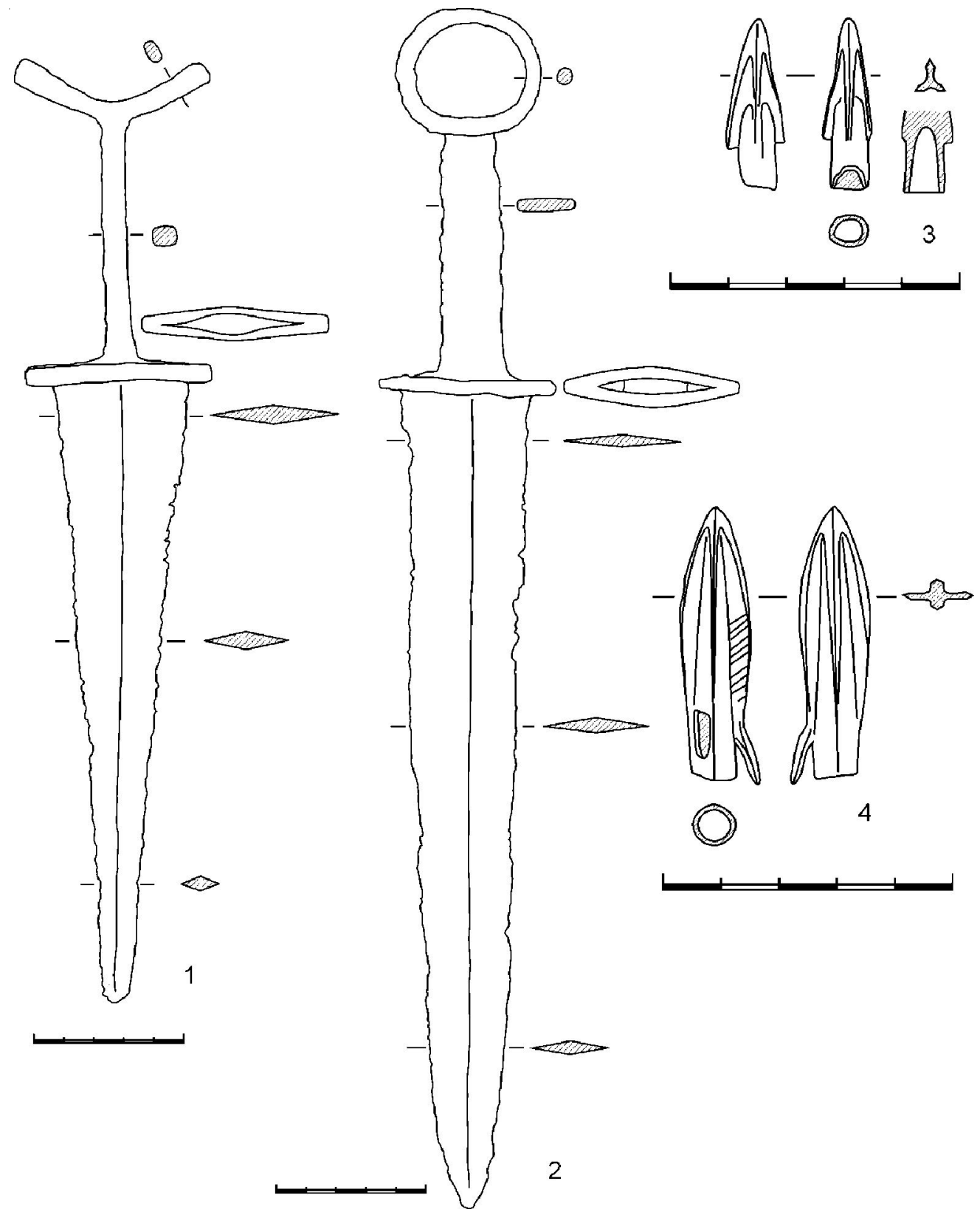

Рис. 5. Случайные находки из фондов Борского музея:

1 - кинжал (БКМ, ОФ № 7706); 2 - кинжал (БКМ, ОФ № 6750);

3 - наконечник стрелы (инвентарный номер отсутствует); 4 - наконечник стрелы (БКМ ОФ № 7810) (1-2 - железо; 3-4 - бронза)

Fig. 5. The Archaeological Collection from the Borsk Museum of Local History:

1 - dagger (BKM, OF No. 7706); 2 - dagger (BKM, OF No. 6750); 3 - arrowhead (no number); 4 - arrowhead (BKM, OF No. 7810) (1-2 - iron; 3-4 - bronze) 


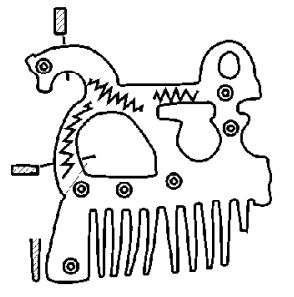

1
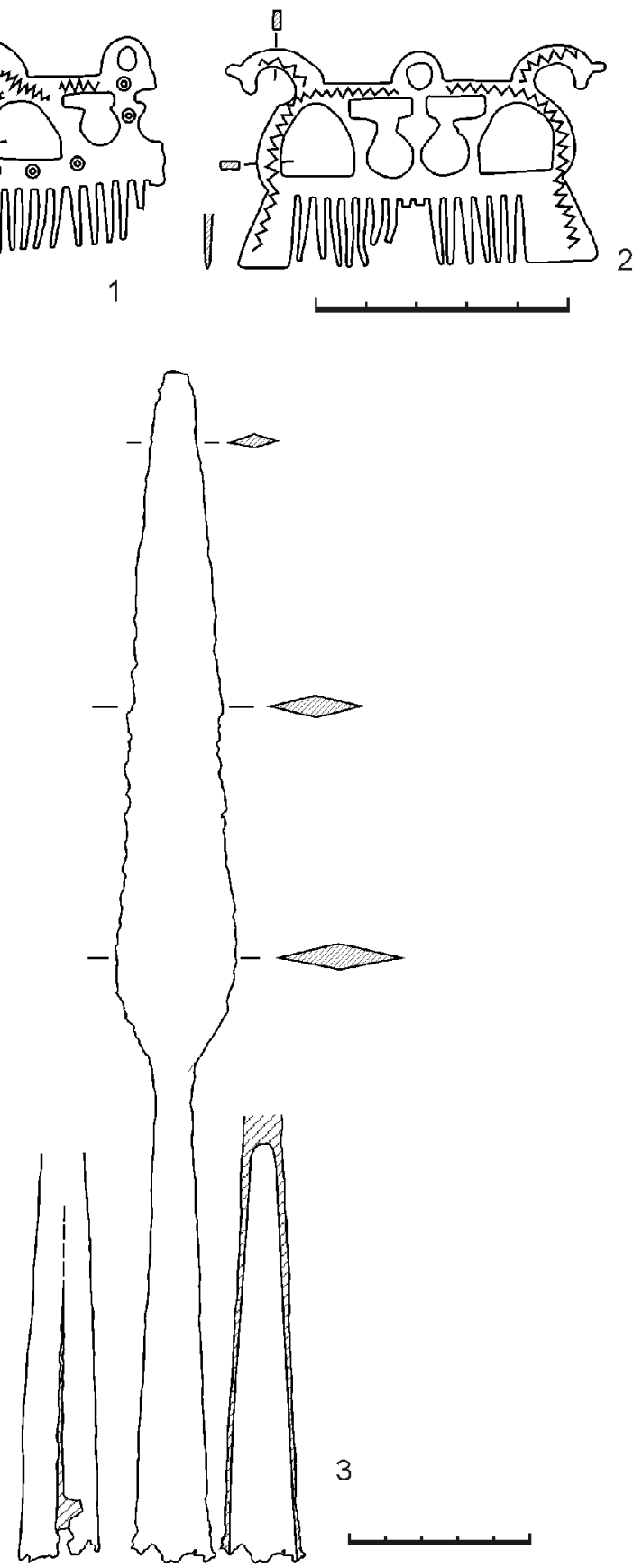
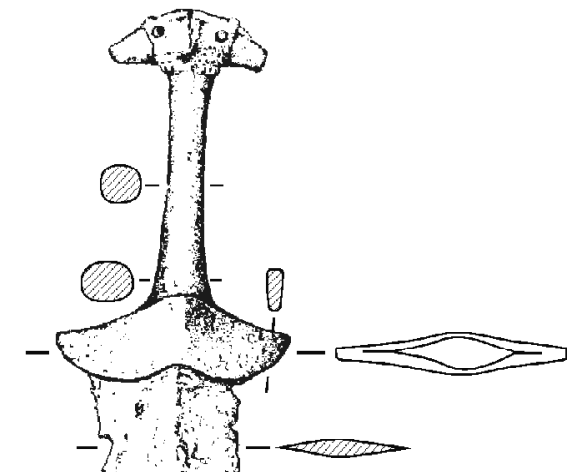

Рис. 6. Случайные находки из фондов Борского музея:

1-2 - гребни (инвентарный номер отсутствует); 3 - наконечник копья (БКМ, ОФ № 6615); 4 - меч (БКМ, ОФ № 6750) (1-2 - бронза; 3-4 - железо)

Fig. 6. The Archaeological Collection from the Borsk Museum of Local History: 1-2 - combs (no number); 3 - spearhead (BKM, OF No. 6615); 4 - sword (BKM, OF No. 6750) (1-2 - bronze; $3-4$ - iron) 


\section{СПИСОК ЛИТЕРАТУРЫ}

Бадер О. Н., Халиков А. Х., 1976. Памятники балановской культуры // Свод археологических источников. Вып. В1-25. М. : Наука. 167 с.

Берестнев С. И., 2001. Восточноукраинская лесостепь в эпоху средней и поздней бронзы (ІІ тыс. дон.э.). Харьков : ПФ Амет. 263 с.

Брюсов А. Я., Зимина М. П., 1966. Каменные сверленые боевые топоры на территории Европейской части СССР // Свод археологических источников. Вып. В4-4. М. : Наука. 97 с.

Васильева И. Н., Салугина Н. П., Кулакова Л. С., 2017. Кротовское I поселение срубной культуры в Самарском Заволжье // Вопросы археологии Поволжья. Вып. 6. Самара : Книжное Издательство. С. 391-473.

Генинг В. Ф., Зданович Г. Б., Генинг В. В., 1992. Синташта. Археологические памятники УралоКазахстанских степей. Кн. 1. Челябинск : ЮжноУральское книжное издательство. 406 с.

Горбунов В. С., 1986. Абашевская культура Южного Приуралья. Уфа : Изд-во БГПИ. 95 с.

Горбунов В. С., Морозов Ю. А., 1991. Некрополь эпохи бронзы Южного Приуралья. Уфа : Башкир. книж. изд-во. 160 с.

Гуцалов С. Ю., 2004. Древние кочевники Южного Приуралья VII-I вв. до н.э. Уральск : Западноказахстанский центр истории и археологии. $136 \mathrm{c}$.

Денисов А. В., Мышкин В. Н., 2008. Клинковое оружие кочевого населения бассейна р. Самары в VII-IV вв. до н.э. // Нижневолжский археологический вестник. Вып. 9. С. 62-75.

Денисов А. В., Мамедов А. М., 2014. О времени и истоках появления клинкового оружия с прямым перекрестием на территории Южного Приуралья // Stratum plus. № 3. C. 157-168.

Дергачев В. А., Бочкарев В. С., 2002. Металлические серпы поздней бронзы Восточной Европы. Кишинев : Высшая Антропологическая Школа : Институт археологии и этнографии AH PM. 348 c.

Евгеньев А. А., Купцова Л. В., Мухаметдинов В. И., Рослякова Н. В., Усачук А. Н., Файзуллин И. А., Хохлов А. А., 2016. Поселение Малоюлдашево I эпохи неолита и поздней бронзы в Западном Оренбуржье. Оренбург : Издательский проект ОГПУ. 196 с.

Ефименко П. П., Третьяков П. Н., 1961. Абашевская культура в Поволжье // Абашевская культура в Среднем Поволжье. Материалы и исследования по археологии СССР. № 97. М. : Наука. C. $43-110$.

Ефименко П. С., 1874. Старинные гребенки в Пинежском уезде, Архангельской губернии // Древ- ности : труды Московского археологического общества. T. IV. Вып. 1. М. С. 49-57.

Збенович В. Г., 1980. Поселение Бернашевка на Днестре (к происхождению трипольской культуры). Киев : Наукова думка. 178 с.

Збруева А. В., 1958. Могильник Метев-Тамак // Краткие сообщения Института истории материальной культуры. Вып. 72. М. ; Л. : Изд-во АН CCCP. С. 28-36.

Исмагилов Р. Б., Скарбовенко В. А., 1977. Новые находки савроматского оружия в междуречье Волги и Урала // Средневолжская археологическая экспедиция. Куйбышев : Куйбышев. гос. ун-т. С. 77-92.

Клепиков В. М., 2007. Раннесарматские мечи в Нижнем Поволжье // Вооружение сарматов: региональная типология и хронология : докл. к VI Междунар. конф. «Проблемы сарматской археологии и истории». Челябинск : Изд-во ЮУрГУ. С. 51-57.

Колев Ю. И., Королев А. И., 2017. Поселение Русская Селитьба II // Вопросы археологии Поволжья. Вып. 6. Самара : Книжное Издательство. С. 526-573.

Кондратьева О. А., 1985. Крестьянские зооморфные металлические гребни и древние традиции в их изготовлении // Памятники культуры. Новые открытия : Ежегодник. 1983. М. : Наука. С. 452-459.

Кондратьева О. А., 2011. Гребни IX - ХІХ вв. в быту, обрядах, фольклоре, ремесле и художественном творчестве Древней Руси - России : Археологические и этнографические очерки. СПб. : Вести. 343 с.

Крайнов Д. А., 1972. Древнейшая история ВолгоОкского междуречья. М. : Наука. 273 с.

Краснов Ю. А., Каховский В. Ф., 1978. Средневековые Чебоксары : материалы Чебоксарской экспедиции 1969-1973 гг. М. : Наука. 192 с.

Кривцова-Гракова О. А., 1948. Алексеевское поселение и могильник // Труды ГИМ. Вып. XVII. М. : ГИМ. С. 59-172.

Кузьмина О. В., 2000. Металлические изделия и вопросы относительно хронологии абашевской культуры // Древние общества юга Восточной Европы в эпоху палеометалла. СПб. : Европейский Дом. С. 65-134.

Кузьмина О. В., 2006. Каменные сверленые топоры Самарского Поволжья // Вопросы археологии Поволжья. Вып. 4. Самара : Научно-технический центр. С. 334-349.

Кузьмина О. В., 2017. І Шигонское поселение // Вопросы археологии Поволжья. Вып. 6. Самара : Книжное Издательство. С. 279-390.

Кузьмина О. В., Колев Ю. И., Ластовский А. А., Турецкий М. А., 2017. Материалы эпохи бронзы поселения Лебяжинка V // Вопросы архе- 
ологии Поволжья. Вып. 6. Самара : Книжное Издательство. С. 124-278.

Лозе И. А., 1966. Некоторые мезолитические находки на территории Латвии // Материалы и исследования по археологии СССР. № 126. М. : Наука. С. 108-113.

Мерперт Н. Я., 1958. Из древнейшей истории Среднего Поволжья // Материалы и исследования по археологии СССР. № 61. М. : Наука. C. 39-154.

Мошкова М. Г., 1963. Памятники прохоровской культуры // Свод археологических источников. Д.1-10. М. : Наука. 34 с.

Мышкин В. Н., Скарбовенко В. А., 2000. Кочевники Самарского Поволжья в раннем железном веке // История Самарского Поволжья с древнейших времен до наших дней. Ранний железный век и средневековье. М. : Наука. С. 9-81.

Обыденнов М. Ф., Горбунов В. С., Муравкина Л. И., Обыденнова Г. Т., Гарустович Г. Н., 2000. Тюбяк: поселение бронзового века на Южном Урале. Уфа : Изд-во БГПУ. 159 с.

Обыденнов М. Ф., Обыденнова Г. Т., 1996. Памятники бронзового века Южного Урала. Уфа : Восточный университет. $104 \mathrm{c}$.

Очир-Горяева М. А., 1996. Наконечники стрел кочевников Нижнего Поволжья // Российская археология. № 1. С. 41-54.

Ошибкина С. В., 1981. Памятники эпохи мезолита в Восточном Прионежье // Краткие сообщения Института археологии. Вып. 165. М. : Наука. C. 92-98.

Ошибкина С. В., 2006. Мезолит Восточного Прионежья. Культура веретье. М. : Изд-во ИА РАН. $322 \mathrm{c}$.

Памятники срубной культуры. Волго-Уральское междуречье, 1993 // Свод археологических источников. Вып. В1-10. Саратов : Изд-во Сарат. ун-та. $200 \mathrm{c}$.

Потемкина Т. М., 1985. Бронзовый век лесостепного Притоболья. М. : Наука. 375 с.

Пряхин А. Д., 1996. Мосоловское поселение металлургов-литейщиков эпохи поздней бронзы. Книга вторая. Воронеж : Изд-во Воронеж. ун-та. 175 с.

Сальников К. В., 1967. Новые материалы по истории племен эпохи бронзы Башкирии // Ученые записки. № 148. Пермь : Изд-во Перм. ун-та. С.72-92.

Сергацков И. В., 2007. Мечи и кинжалы среднесарматских памятников Нижнего Поволжья // Boоружение сарматов: региональная типология и хронология : докл. к VI Междунар. конф. «Проблемы сарматской археологии и истории». Челябинск : Изд-во ЮУрГУ. С. 58-65.
Симоненко А. В., 2009. Сарматские всадники Северного Причерноморья. СПб. : Факультет филологии и искусств СПбГУ. 328 с.

Синицын И. В., 1946. К материалам по сарматской культуре на территории Нижнего Поволжья // Советская археология. № VIII. C. 73-95.

Синюк А. Т., Клоков А. Ю., 2000. Древнее поселение Липецкое Озеро. Липецк : Липецкое издание. 158 c.

Скрипкин А. С., 1990. Азиатская Сарматия. Проблемы хронологии и ее исторический аспект. Саратов : Изд-во Сарат. ун-та. 303 с.

Смирнов К. Ф., 1961. Вооружение савроматов // Материалы и исследования по археологии СССР. № 101. М. : Наука. 166 с.

Смолин В. Ф., 1928. Абашевский могильник в Чувашской республике (очерк археологических раскопок в 1925 году) // Труды общества изучения Чувашского края. Т. 1, вып. 1. Чебоксары : Изд-во Общества изучения Чувашского края. С. 3-56.

Соколов П. М., 2010. Типология и хронология наконечников стрел савроматской археологической культуры Нижнего Поволжья // Нижневолжский археологический вестник. Вып. 11. C. $213-232$.

Хазанов А. М., 2008. Очерки военного дела сарматов. СПб. : Изд-во СПбГУ. 294 с.

Шутова Н. И., 2001. Дохристианские культовые памятники в удмуртской религиозной традиции. Опыт комплексного исследования. Ижевск : Удмуртский институт истории, языка и литературы УрО РАН. 304 с.

\section{REFERENCES}

Bader O.N., Khalikov A.Kh., 1976. Monuments of the Balanovo Culture. Svod arkheologicheskikh istochnikov. Iss. B1-25. Moscow, Nauka Publ. $167 \mathrm{p}$.

Berestnev S.I., 2001. East-Ukrainian Forest-Steppe in the Epoch of Middle and Late Bronze (II ${ }^{\text {nd }}$ Millennium BC). Kharkov, PF Amet Publ. $263 \mathrm{p}$.

Bryusov A.Ya., Zimina M.P., 1966. Stone Drilled Battle Axes on the Territory of the European Part of the USSR. Svod arkheologicheskikh istochnikov. Iss. B4-4. Moscow, Nauka Publ. $97 \mathrm{p}$.

Vasilyeva I.N., Salugina N.P., Kulakova L.S., 2017. Krotovskoe I Settlement of Log Culture in the Samara Zavolzhye. Voprosy arkheologii Povolzhya. Iss. 6. Samara, Knizhnoe izd-vo Publ, pp. 391-473. 
Gening V.F., Zdanovich G.B., Gening V.V., 1992. Sintashta. Archaeological Monuments of the Ural-Kazakhstan Steppes. Book 1. Chelyabinsk, Yuzhno-uralskoe knizhnoe izd-vo. $406 \mathrm{p}$.

Gorbunov V.S., 1986. Abashevskaya Culture of the Southern Urals. Ufa, Izd-vo BGPI. 95 p.

Gorbunov V.S., Morozov Yu.A., 1991. Necropolis of the Bronze Age of the Southern Urals. Ufa, Bashkirskoe knizhnoe izd-vo. 160 p.

Gutsalov S.Yu., 2004. Ancient Nomads of the Southern Urals of the $7^{\text {th }}-1^{\text {st }}$ Centuries. BC. Uralsk, Zapadno-Kazakhstanskiy tsentr istorii i arkheologii. $136 \mathrm{p}$.

Denisov A.V., Myshkin V.N., 2008. Wedge-Shaped Weapons of the Nomadic Population from the Territory of the Samara River in the $7^{\text {th }}-$ $4^{\text {th }}$ Centuries BC. The Lower Volga Archaeological Bulletin, iss. 9, pp. 62-75.

Denisov A.V., Mamedov A.M., 2014. About the Time and the Origins of Bladed Weapons with Rectangular Hilt in the Southern Urals. Stratum plus, no. 3, pp. 157-168.

Dergachev V.A., Bochkarev V.S., 2002. Metal Sickles of the Late Bronze in Eastern Europe. Kishinev, Vysshaya Antropologicheskaya Shkola. Institut Archeologii i Etnografii AN RM. 348 p.

Evgenyev A.A., Kuptsova L.V., Mukhametdinov V.I., Roslyakova N.V., Usachuk A.N., Fayzullin I.A., Khokhlov A.A., 2016. Settlement of the Maloyuldashevo I of the Neolithic and Late Bronze Ages in the Western Orenburg Region. Orenburg, OGPU Publ. $196 \mathrm{p}$.

Efimenko P.P., Tretyakov P.N., 1961. The Abashevo Culture in the Volga Region. Abashevskaya kultura v Srednem Povolzhye. Materialy $i$ issledovaniya po arkheologii SSSR, no 97. Moscow, Nauka Publ., pp. 43-110.

Efimenko P.S., 1874. Ancient Combs in the Pinezhsky Uyezd, Arkhangelsk Province. Drevnosti: trudy Moskovskogo Archeologicheskogo Obshchestva, vol. IV, iss. 1. Moscow, pp. 49-57.

Zbenovich V.G., 1980. The Settlement of Bernashevka on the Dniester (to the Origin of Trypillian Culture). Kiev, Naukova Dumka Publ. 178 p.

Zbrueva A.V., 1958. The Burial Ground Metev-Tamak. Kratkie soobshcheniya instituta istori materialnoy kultury, iss. 72. Moscow; Leningrad, Izd-vo AN SSSR, pp. 28-36.

Ismagilov R.B., Skarbovenko V.A., 1977. New Finds of the Sauromatian Weapons in the Interfluve of the Volga and the Urals. Srednevolzhskaya arkheologicheskaya ekspeditsiya. Kuybyshev, Izd-vo KubGU, pp. 77 - 92.

Klepikov V.M., 2007. Early Sarmatian Swords in the Lower Volga Region. Vooruzhenie sarmatov: regionalnaya tipologiya $i$ khronologiya: doklady k VI Mezhdunarodnoy konferentsii "Problemy sarmatskoy arkheologii $i$ istorii". Chelyabinsk, Izd-vo YuUrGU, pp. 51-57.

Kolev Yu.I., Korolev A.I., 2017. The Settlement Russian Selitba II. Voprosy arkheologii Povolzhya, iss. 6. Samara, Knizhnoe izd-vo, pp. 526-573.

Kondratyeva O.A., 1985. Peasant Zoomorphic Metal Ridges and Ancient Traditions in Their Manufacture. Pamyatniki kultury. Novye otkrytiya: Ezhegodnik. 1983. Moscow, Nauka Publ., pp. 452-459.

Kondratyeva O.A., 2011. The Crests of the $9^{\text {th }}-$ $19^{\text {th }}$ Centuries in Everyday Life, Rituals, Folklore, Craft and Artistic Creativity of Ancient Rus-Russia: Archaeological and Ethnographic Essays. Saint Petersburg, Vesti Publ. 343 p.

Kraynov D.A., 1972. The Ancient History of the VolgaOka Interfluve. Moscow, Nauka Publ. 273 p.

Krasnov Yu.A., Kakhovskiy V.F., 1978. Medieval Cheboksary: Materials of the Cheboksary Expedition of 1969-1973. Moscow, Nauka Publ. $192 \mathrm{p}$.

Krivtsova-Grakova O.A., 1948. The Alekseevskoe Settlement and the Alekseevsky Burial Ground. Trudy GIM, iss. XVII. Moscow, Gosudarstvennyy istoricheskiy muzey Publ., pp. 59-172.

Kuzmina O.V., 2000. Metal Products and Questions Concerning the Chronology of the Abashev Culture. Drevnie obshchestva yuga Vostochnoy Evropy v epokhu paleometalla. Saint Petersburg, Evropeyskiy dom Publ., pp. 65-134.

Kuzmina O.V., 2006. Stone Drilled Axes of the Samara Volga Region. Voprosy arkheologii Povolzhya, iss. 4. Samara, Nauchno-tekhnicheskiy tsentr Publ., pp. 334-349.

Kuzmina O.V., 2017. I Shigonskoe Settlement. Voprosy arkheologii Povolzhya, iss. 6. Samara, Knizhnoe izd-vo, pp. 279-390.

Kuzmina O.V., Kolev Yu.I., Lastovsky A.A., Turetsky M.A., 2017. Materials of the Bronze Epoch of the Settlement of Lebyazhinka V. Voprosy arkheologii Povolzhya, iss. 6. Samara, Knizhnoe izd-vo, pp. 124-278.

Loze I.A., 1966. Some Mesolithic Findings in the Territory of Latvia. Materialy i issledovanija po arheologii SSSR, no. 126. Moscow, Nauka Publ., pp. 108-113.

Merpert N.Ya., 1958. From the Ancient History of the Middle Volga Region. Materialy i issledovaniya po arkheologii SSSR, no. 61. Moscow, Nauka Publ., pp. 39-154.

Moshkova M.G., 1963. Monuments of the Prokhorovka Culture. Svod arkheologicheskikh istochnikov, iss. D1-10. Moscow, Nauka Publ. 34 p.

Myshkin V.N., Skarbovenko V.A., 2000. Nomads of the Samara-Volga Region in the Early Iron Age. 
The Archaeological Collection from the Borsk Museum of Local History

Istoriya Samarskogo Povolzhya s drevneyshikh vremen do nashikh dney. Ranniy zheleznyy vek $i$ srednevekovye. Moscow, Nauka Publ., pp. 9-81.

Obydennov M.F., Gorbunov V.S., Muravkina L.I., Obydennova G.T., Garustovich G.N., 2000. Tyubyak: Bronze Age Settlement in the Southern Urals. Ufa, Izd-vo BGPU. 159 p.

Obydennov M.F., Obydennova G.T., 1996. Monuments of the Bronze Age of the Southern Urals. Ufa, Vostochnyy universitet Publ. $104 \mathrm{p}$.

Ochir-Goryaeva M.A., 1996. The Nomad Arrow-Heads from the Low Volga River Region. Rossiyskaya arkheologiya, no. 1, pp. 41-54.

Oshibkina S.V., 1981. Monuments of the Mesolithic Age in the Eastern Prionezhye. Kratkie soobshcheniya instituta arkheologii, iss. 165. Moscow, Nauka Publ., pp. 92-98.

Oshibkina S.V., 2006. Mesolithic of the Eastern Prionezhye. The Veretye Culture. Moscow, Izd-vo IA RAN. 322 p.

Monuments of the Srubna Culture. The Volga-Ural Interfluve, 1993. Svod arkheologicheskikh istochnikov, iss. B1-10. Saratov, Izd-vo Saratovskogo un-ta. $200 \mathrm{p}$.

Potemkina T.M., 1985. The Bronze Age of the ForestSteppe of the Tobolsk Region. Moscow, Nauka Publ. 375 p.

Pryakhin A.D., 1996. Mosolovskoye Settlement of Metallurgists-Casters of the Late Bronze Age. The Second Book. Voronezh, Izd-vo Voronezhskogo un-ta. $175 \mathrm{p}$.

Salnikov K.V., 1967. New Materials on the History of Tribes of the Bronze Age of Bashkortostan. Uchenye zapiski, no. 148. Perm, Izd-vo Permskogo un-ta, pp.72-92.

Sergatskov I.V., 2007. Swords and Daggers of Middle Sarmatian Monuments of the Lower Volga
Region. Vooruzhenie sarmatov: regionalnaya tipologiya i khronologiya: doklady k VI Mezhdunarodnoy konferentsii "Problemy sarmatskoy arkheologii i istorii”. Chelyabinsk, Izd-vo YuUrGU, pp. 58-65.

Simonenko A.V., 2009. The Sarmatian Riders of the North Pontic Region. Saint Petersburg, Saint Petersburg State University, Faculty of Philology and Arts. 328 p.

Sinitsyn I.V., 1946. To the Materials on the Sarmatian Culture on the Territory of the Lower Volga Region. Sovetskaya arkheologiya, no. VIII, pp. 73-95.

Sinyuk A.T., Klokov A.Yu., 2000. Ancient settlement Lipetsk Lake. Lipetsk, Lipetsk edition. 158 p.

Skripkin A.S., 1990. Asian Sarmatia. Problems of Chronology and its Historical Aspect. Saratov, Izd-vo Saratovskogo un-ta. 303 p.

Smirnov K.F., 1961. Armament of the Sauromatians. Materialy $i$ issledovaniya po arkheologii SSSR, no. 101. Moscow, Nauka Publ. 166 p.

Smolin V.F., 1928. The Abashevsky Burial Ground in the Chuvash Republic (an Outline of Archaeological Excavations in 1925). Trudy obshchestva izucheniya Chuvashskogo kraya, vol. 1, iss. 1. Cheboksary, Izd-vo Obshchestva izucheniya Chuvashskogo kraya, pp. 3-56.

Sokolov P.M., 2010. Typology and Chronology of Sauromatian Arrowheads from the Lower Volga Area. The Lower Volga Archaeological Bulletin, iss. 11, pp. 213-232.

Khazanov A.M., 2008. Essays on the Art of Warfare of the Sarmatians. Saint Petersburg, Izd-vo SPbGU. $294 \mathrm{p}$.

Shutova N.I., 2001. Pre-Christian Cult Monuments in the Udmurt Religious Tradition. Experience in Complex Research. Izhevsk, Udmurtskiy institut istorii, yazyka i literatury UrO RAN. 304 p.

\section{Information about the Authors}

Ekaterina V. Volkova, Deputy Director for Research, Research and Production Center Bifas, Gagarina St., 86, 443045 Samara, Russian Federation, katerinathewolf@gmail.com.

Aleksey V. Denisov, Researcher of Archaeological Laboratory, Samara State University of Social Sciences and Education, M. Gorkogo St., 65/67, 443099 Samara, Russian Federation, sarmat_samara@mail.ru.

Olga V. Kuzmina, Candidate of Sciences (History), Researcher, Samara Archaeological Society, Leninskaya St., 142, 443041 Samara, Russian Federation, kuzmina.o.v@gmail.com.

Aleksey A. Lastovskiy, Senior Researcher, Research and Production Center Bifas, Gagarina St., 86, 443045 Samara, Russian Federation, al_al_lastovsky@mail.ru.

\section{Информация об авторах}

Екатерина Вячеславовна Волкова, заместитель директора по научно-исследовательской работе, научно-производственный центр «Бифас», ул. Гагарина, 86, 443045 г. Самара, Российская Федерация, katerinathewolf@gmail.com. 
Алексей Владимирович Денисов, научный сотрудник, Самарский государственный социально-педагогический университет, ул. М. Горького, 65/67, 443099 г. Самара, Российская Федерация, sarmat_samara@mail.ru.

Ольга Викторовна Кузьмина, кандидат историчеких наук, научный сотрудник, Самарское археологическое общество, ул. Ленинская, 142, 443041 г. Самара, Российская Федерация, kuzmina.o.v@gmail.com.

Алексей Алексеевич Ластовский, старший научный сотрудник, научно-производственный центр «Бифас», ул. Гагарина, 86, 443045 г. Самара, Российская Федерация, al_al_lastovsky@mail.ru. 